\title{
Second Impressions: Expanding the Range of Cereals from Early Neolithic Franchthi Cave, Greece
}

\author{
Susan E. Allen ${ }^{1 *}$ \\ ${ }^{1}$ Department of Anthropology, University of Cincinnati, Cincinnati, USA. \\ *susan.allen@uc.edu
}

\begin{abstract}
The southern Greek archaeological site of Franchthi Cave, with occupation dating from the Upper Paleolithic, remains the only site in southern Greece that both spans the shift from foraging to farming and has produced systematically recovered plant remains associated with this important transition in human prehistory. Previously reported archaeobotanical remains from the site derive exclusively from the cave interior, as none were recovered from outside the cave on the Franchthi Cave Paralia. This article reports the first evidence for plant use in the settlement area outside the cave, as provided by five seed impressions in Early Neolithic ceramic sherds from the Paralia. Significantly, this new data expands the range of crops represented at the site during the Early Neolithic to include einkorn wheat (Triticum monococcum L.), pushing back its appearance at Franchthi by several centuries.
\end{abstract}

Received July 26, 2017

OPEN ӘACCESS

Accepted July 14, 2018

DOI 10.14237/ebl.9.2.2018.1065

Keywords Archaeobotany, Europe, Seed impressions, Early Neolithic, Einkorn, Triticum monococcum

Copyright (c) 2018 by the author(s) licensee Society of Ethnobiology. This is an open-access article distributed under the terms of the Creative Commons Attribution-NonCommercial 4.0 International Public License (https://creativecommons.org/licenses/by-nc/4.0), which permits non-commercial use, distribution, and reproduction in any medium, provided the original author and source are credited.

\section{Introduction}

The archaeological site of Franchthi Cave in the southern Argolid peninsula of Greece (Figure 1) is significant both for its contribution to a methodological shift in Aegean prehistoric archaeology and for its status as one of the few sites in southern Europe that spans the shift from foraging to farming that accompanies the transition from the Mesolithic to Neolithic in Greece. During excavations directed by T.W. Jacobsen between 1967 and 1979, intensive sampling for plant remains was undertaken in four trenches within the cave (Hansen 1991), producing the first botanical assemblage associated with the transition to farming in southeastern Europe. In Hansen's (1991) stratigraphic classification of the plant remains, Botanical Zone V/VI corresponds to the disturbed strata immediately overlying the postMesolithic occupational hiatus, and Zone VI to the earliest Neolithic deposits (Hansen 1991). While the domesticated crops Triticum dicoccum Schübl. (emmer), Hordeum vulgare L. (hulled barley), and Lens culinaris L. (lentil) were all identified in Zone VI, no Triticum monococcum L. (einkorn wheat) was recovered.Hansen's Zone VI corresponds to Perlès' Lithic Phase X, the "néolithique initial' (Perlès 1987:94) or Initial Neolithic (IN), the earliest phase of Early Neolithic (EN) at Franchthi. The Franchthi IN dates to the first half of the seventh millennium BC, contemporary with the earliest Neolithic sites in northern Greece and Crete (Perlès 2001, Perlès et al. 2013). Because the cave deposits situated between the IN and Middle Neolithic showed disturbed stratigraphy (Hansen 1991:144; Vitelli 1993:256), the plant remains from Hansen's Zone VI/VII do not provide evidence for plant use that can be unequivocally associated with the later phases of EN. Instead, they likely represent a mixing of the latest IN and later deposits (Hansen 1991:144). As such, despite its small size (38 whole items, 28 fragments [Hansen 1991]), the Franchthi IN assemblage from Zone VI represents the only securely EN plant remains not only for the site, but also for the southern Greek mainland as a whole (Megaloudi 1996; Perlès 2001; Valamoti and Kotsakis 2007).

In contrast to the intensive botanical sampling implemented within the cave, no plant remains were recovered from the Franchthi Paralia (beach; hereafter "Paralia"), the area in front of the cave, which was the primary location of post-Mesolithic settlement. As 


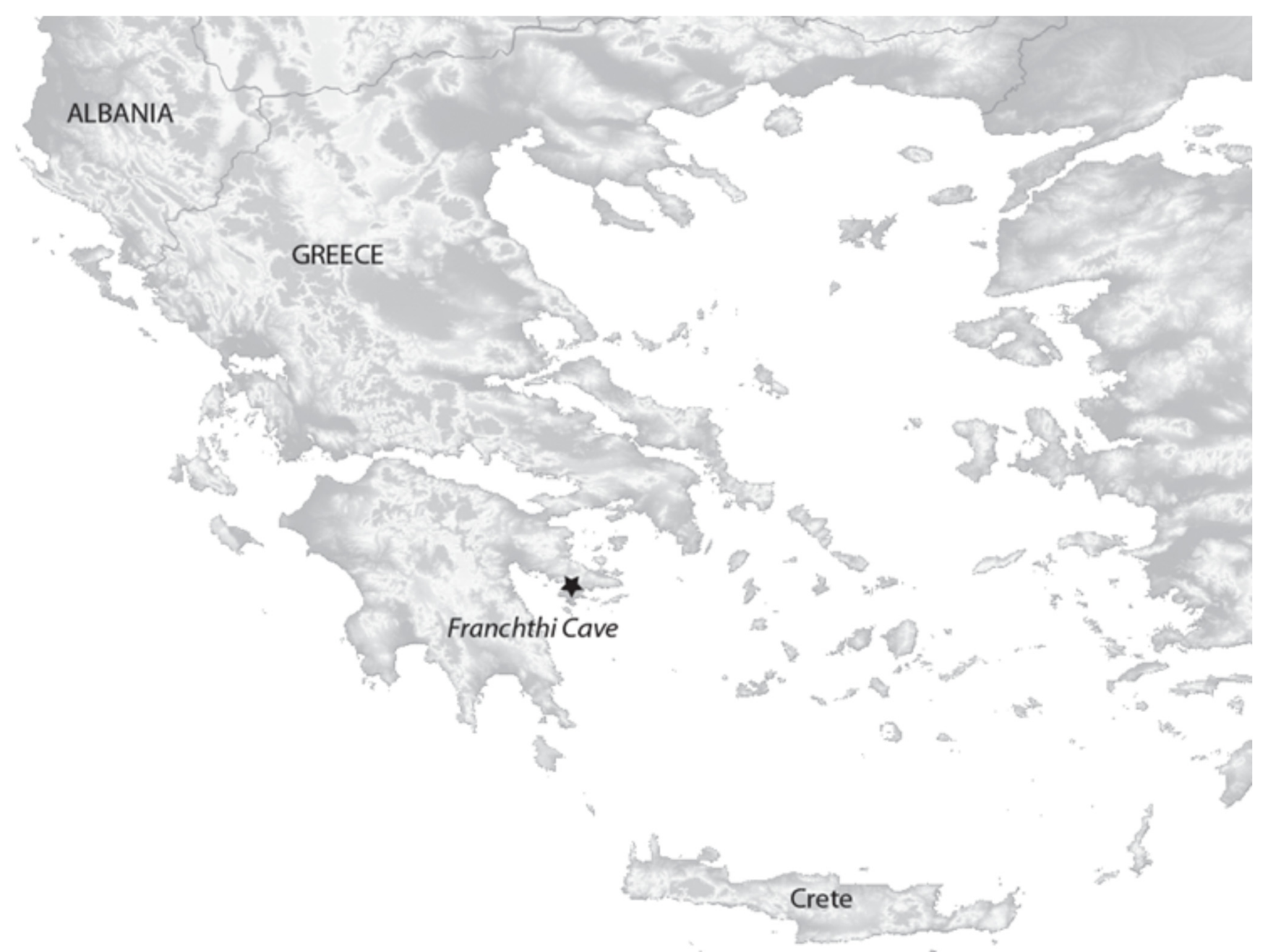

Figure 1 Map showing location of Franchthi Cave (Prepared by John Wallrodt).

such, the newly rediscovered plant impressions from EN ceramic sherds from the Paralia that are discussed here provide not only the first botanical evidence from this area of the site, but also the first EN evidence that postdates the Franchthi IN. More significantly, these impressions expand the EN range of taxa to include Triticum monococcum L. (einkorn wheat), and push back its appearance at Franchthi from Middle to Early Neolithic, a difference of several centuries. ${ }^{1}$ Prior to this new evidence, the earliest record of einkorn at Franchthi consisted of seeds and chaff (spikelet forks) recovered from Hansen's (1991) Franchthi Botanical Zone VIIa, corresponding to Vitelli's (1993) ceramic phases FCP 2.2 (Trench FAS) and FCP 2.3 (Trench FAN) and dating to the second phase of the Middle Neolithic.

\section{Methods}

During her analysis of the Franchthi ceramics, Vitelli
(1993) selected five sherds with apparent seed impressions for further analysis (Table 1). All five sherds originate from Trench Q5N on the Paralia and are $\mathrm{EN}$ in date. Four of these were characterized by Vitelli (1993) as belonging to the earliest EN Franchthi Cave Pottery (FCP) phase (FCP1), while the fifth was characterized as belonging to FCP Interphase 1/2. Hansen applied latex to the impressions to create casts of their forms for identification. In total, Hansen recovered five plant impressions. These casts were discovered in 2015 among a set of plant impression casts that Hansen made from architectural clay fragments recovered from the Bronze Age site of Tsoungiza, at which she supervised archaeobotanical recovery.

According to Hansen (personal communication), she largely followed the latex casting methods outlined by Renfrew (1973:16) as "pouring a latex 
Table 1 Plant impressions recovered from Early Neolithic sherds from the Franchthi Paralia.

\begin{tabular}{llll}
\hline Sherd & FCP Ware type & FCP Phase & Identification \\
\hline Q5N29 & EN Burnished & FCP 1 & cf. Cereal grain indet. \\
Q5N55 & EN Lime Temper & FCP 1 & cf. Triticum sp. (in glumes) \\
Q5N16 & EN Burnished, no Lime & FCP 1 & Triticum monococcum L. \\
Q5N16 & EN Burnished, no Lime & FCP 1 & Triticum monococcum L. \\
Q5N54 & EN Lime Temper & FCP 1/2 & cf. Triticum sp. \\
\hline
\end{tabular}

solution into the cavity exposed on the surface of the pot, allowing it to set in the air, and then extracting a positive cast of the original grain." Hansen improved on this method by using a large bore hypodermic needle to inject latex into the sherds in order to ensure that the voids were completely filled, then tapping the sherd lightly on a hard surface to release any trapped air bubbles. She then placed a small piece of gauze over the latex to facilitate extraction of the cast after drying.

Analysis of the seed impressions took place in the Mediterranean Ecosystems Dynamics and Archaeology Laboratory at the University of Cincinnati. Seed identifications were made with use of stereoscopic microscopy at magnifications of 10-40x. All impressions were photographed and measured (length, breadth, and thickness). Identification followed morphometric criteria for cereal determination, as outlined by Renfrew (1973), Hubbard (1992), and Jacomet (2006).

\section{Results}

The seed impression identifications and the ceramic ware types for the associated sherds, as identified by Vitelli (1993), are shown in Table 1. Two examples of Triticum monococcum L. (einkorn) impressions were identified (Figure 2). Both occur on sherd Q5N16, an EN Burnished No Lime sherd (Vitelli 1993). The identification of einkorn was based on morphometric characteristics, particularly the narrowness of the grains and their somewhat attenuated shape with pointed ends, as reflected in their low ratios of breadth to thickness (B:T) and breadth to length (B:L)
(Table 2). These specimens are similar in outline to Middle Neolithic specimens of einkorn illustrated by Hansen (1991, Figures 38 and 41). ${ }^{2}$ A third impression was identified only as Triticum sp. (wheat) due to incomplete preservation of its dimensions. Its status as wheat, rather than barley, is based on the rounded apex and ventral surface of the grain, which contrasts with the flattened apex and ventral surface of barley grains. In addition, the ventral furrow of the preserved specimen lacks the angular form characteristic of barley. A fourth impression was identified as an indeterminate seed with morphometric characteristics consistent with a cereal grain, but lacking distinctive characteristics needed for identification as either wheat or barley (Q5N29, Early Neolithic Burnished).

\section{Dimensions of Seed Impressions}

Measurements of length (L), breadth (B), and thickness $(\mathrm{T})$ of the two complete grain impressions identified as einkorn (Table 2) support this identification. For einkorn, breadth to thickness (B:T) ratios are typically less than one, with a range of 0.69 to 1.20 , whereas in emmer B:T is usually greater than one (Jacomet 2006). The Franchthi specimens' B:T ratios of 1.06 and 1.17 fall at the higher end of the range reported by Jacomet (2006) and slightly exceed the generalization of a B:T ratio of "less than one" for einkorn; indeed, they fall within the range of overlap and therefore are consistent with both einkorn and emmer B:T ratios reported by Jacomet (2006). Although Hansen (1991:83, Table 13) reports maximum, minimum, and average measures for L, B, and $\mathrm{T}$ for the einkorn specimens recovered from

Table 2 Measurements of Triticum monococcum L. impressions (in $\mathrm{mm}$ ).

\begin{tabular}{llllll}
\hline Specimen & Length $(\mathrm{L})$ & Breadth $(\mathrm{B})$ & Thickness $(\mathrm{T})$ & $\mathrm{B}: \mathrm{T}$ & $\mathbf{B} / \mathbf{L}^{*} \mathbf{1 0 0}$ \\
\hline QN516a & 7.17 & 3.08 & 2.90 & 1.06 & 42.96 \\
Q5N16b & 7.97 & 3.16 & 2.69 & 1.17 & 39.65 \\
\hline
\end{tabular}




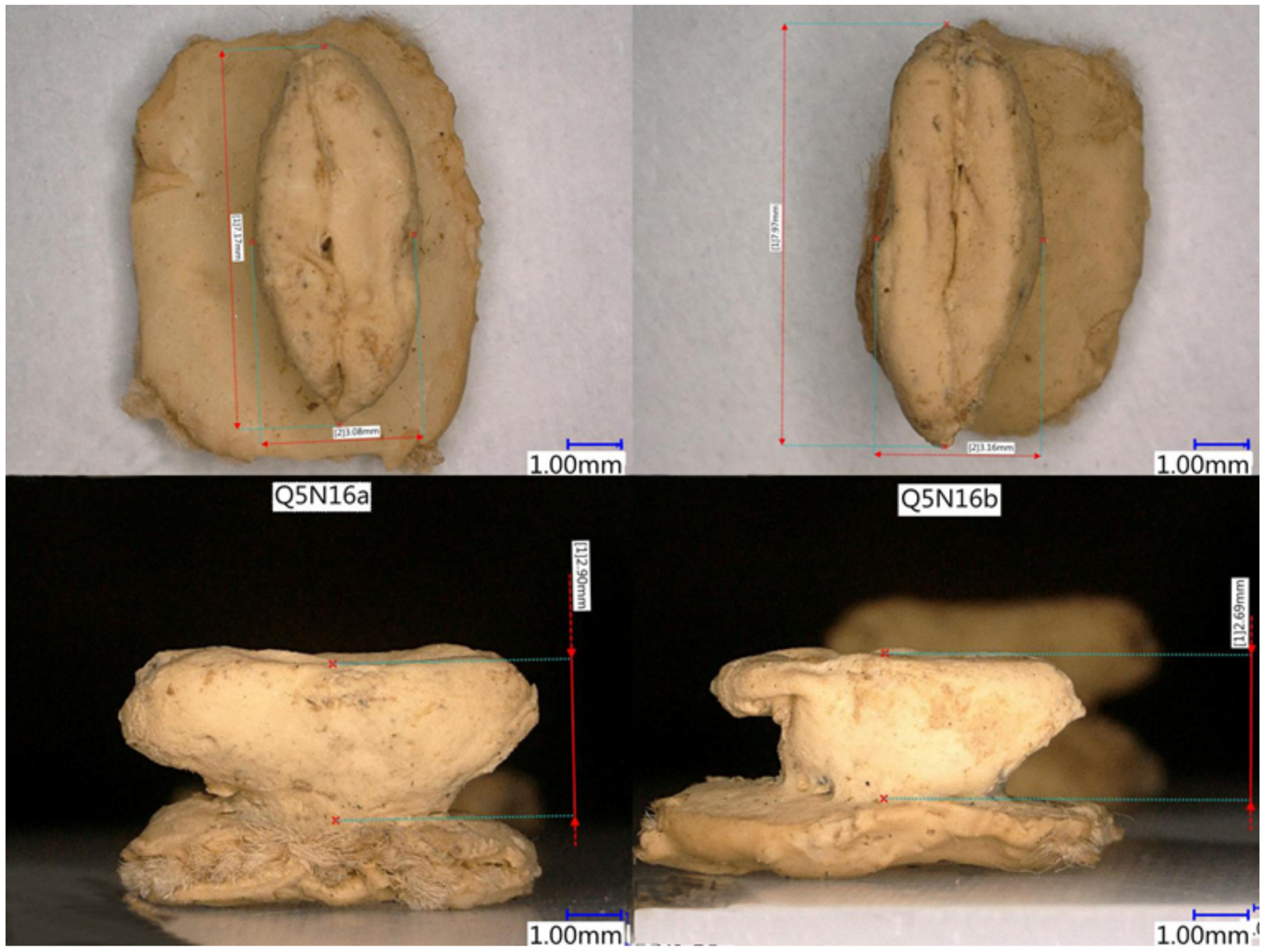

Figure 2 Einkorn impressions on sherd Q5N16, ventral view (a) and lateral view (b).

Zone VII, these aggregate measures unfortunately do not allow for direct comparison of B:T ratios for the impressions with those of individual seed specimens from the cave.

One possible explanation for the Franchthi specimens' position at the top of the B:T range for einkorn is that their dimensions may reflect an expansion of seed breadth with the uptake of water by grains when embedded in wet clay, as demonstrated by Helbaek (1955) and discussed by Renfrew (1973). In his soaking experiment, Helbaek found that breadth increases were most significant (mean increase of $0.37 \mathrm{~mm} \mathrm{[14 \% ]),} \mathrm{followed} \mathrm{by}$ thickness (mean increase of $0.54 \mathrm{~mm}[12 \%]$ ), and that length increased only slightly (mean increase of 0.11 mm [1\%]) (Helbaek 1955:654).
However, two alternative explanations are more likely. The first of these is the difficulty of measuring the full thickness of the specimens due to their orientation in the pottery profile with the dorsal margin of the seed embedded in the base of the latex cast (Figure 2b). Another potential explanation for relatively high B:T ranges for these specimens is the possibility that they represent two-grained einkorn, which, according to Hubbard (1992), shows higher $B: T$ ranges than single-grained einkorn. Measurable specimens of both one-grained $(\mathrm{n}=22)$ and twograined $(n=6)$ einkorn were identified in the Zone VII (Middle Neolithic-Final Neolithic) deposits at Franchthi. Although the presentation of aggregate measures for these specimens does not allow calculation of the B:T ratios for individual grains, the aggregate average measurements produce ratios of 
0.85 and 1.27 for the recovered one- and two-grained einkorn, respectively (Hansen 1991:83, Tables 13 and 14).

While Kroll (1992) has demonstrated that emmerlike two-grained einkorn is not generally distinguishable from emmer, the two specimens of einkorn identified from the Franchthi impressions are more consistent in outline with einkorn than emmer, given their relatively straight sides and acuminate ends, and can be said to be "emmer-like" only in the flatness of their ventral surfaces when viewed from the side. When viewed laterally, however (Figure 2b), their more trigonous outline, consistent with einkorn, is more apparent.

While the $\mathrm{B}: \mathrm{T}$ ratios for these specimens are inconclusive, the breadth and length measurements for these specimens provide more compelling evidence for their identification as einkorn. Due to the long, narrow shape of its grains, einkorn typically shows values of less than 50 for $\mathrm{B} / \mathrm{L}^{*} 100$, whereas emmer values are usually around 54, with a typical range of 48.33 to 60.38 (Jacomet 2006:20-21). The Franchthi impressions' B/L*100 values of 42.96 and 37.38 are consistent with those calculated on the basis of the average $B$ and $L$ values for carbonized einkorn reported by Hansen (1991: Tables 13 and 14). The resulting $\mathrm{B} / \mathrm{L} * 100$ value for single-grained einkorn $(n=22)$ is 42.83 , and that of two-grained einkorn $(n=6)$ is 44.08. For both the carbonized specimens and the impressions, the $\mathrm{B} / \mathrm{L} * 100$ values reflect the grains' elongate forms and point clearly toward einkorn, rather than emmer, as the identification most likely to be correct.

\section{Discussion}

The revolutionary adoption of a systematic and intensive sampling strategy for the recovery of plant remains at Franchthi Cave (Hansen 1991) marked a methodological paradigm shift in Aegean prehistoric archaeology. For the first time on an excavation in Greece intensive water-sieving was used for the recovery of plant remains. Four trenches within the cave were selected for collection of $100 \%$ of the excavated deposits for water-sieving, in order to maximize the recovery of plant remains (Hansen 1991:24). Because of this, despite the stratigraphic break that marks the Mesolithic to Neolithic transition at Franchthi, its archaeobotanical assemblage for the IN phase (Botanical Zone VI, represented only in Trenches FAN and FAS) retains exceptional importance not only as the first to document the shift to agricultural economies in Greece (Hansen 1991; Hansen and Renfrew 1978), but as the only EN botanical assemblage for the southern Greek mainland (Megaloudi 1996; Perlès 2001; Valamoti and Kotsakis 2007).

At Franchthi, the earliest Neolithic deposits are now unambiguously dated to the early seventh millennium BC (prior to 6,500 cal BC) on the basis of recent AMS dates for four emmer grains (FAN 163 GifA 11016, FAN 163 GifA 11455, FAN 162 GifA 11017, and FAN 162 GifA 11456) from trench FAN (Perlès et al. 2013). The dated specimens originate from Hansen's Botanical Interzone V/VI, the Mesolithic and Neolithic interface. Although the Franchthi botanical evidence was initially thought to represent an autochthonous domestication (Hansen and Renfrew 1978), this interpretation was later revised upon closer examination of the evidence. According to Hansen (1991:138), "there is no true transition between Zones $\mathrm{V}$ and VI, but rather an abrupt change in botanical sequence." On the basis of archaeobotanical, faunal, and lithostratigraphic evidence, Hansen (1991:141) argued for a transition to agriculture at Franchthi brought about by a new group of people who reoccupied the cave following the Mesolithic hiatus.

Despite intensive sampling within the cave, only a small collection of plant remains was recovered from Zone VI, which corresponds to Perlès' (1987) Lithic Zone $\mathrm{X}$, the Initial Neolithic. In total, the IN assemblage consists of just 38 whole and 28 fragmentary items from FAS and FAN (Hansen 1991: Appendix A, Appendix D). Hansen postulated that the low frequency of plant remains within the cave could be explained by a focus of plant processing and other plant-related behaviors in the Paralia area in front of the cave (Hansen 1991:141): "if a Neolithic settlement had been developed on the terrace below the cave . . . we could expect that the bulk of plant resources would have been stored, processed, and consumed there rather than inside the cave" (Hansen 1991:141). However, due to the lack of sampling for botanical remains on the Paralia and perhaps also preservation biases, no plant remains whatsoever were recovered from its Early Neolithic deposits (Hansen 1991).

The Franchthi IN botanical assemblage includes emmer wheat, hulled barley, and lentil, but not einkorn. The absence of einkorn at Franchthi during this earliest EN phase contrasts with the pattern seen 
at the majority of EN sites in central and northern Greece, where both emmer and einkorn are present (Marinova and Valamoti 2014; Perlès 2001; Valamoti and Kotsakis 2007). At Franchthi, einkorn is not attested in the macrobotanical assemblage from the cave interior until the Middle Neolithic in Botanical Zone VIIb (approximately $6800 \mathrm{BP}$ to $5260+/-60$ BP; Hansen 1991:145), and occurs in much lower frequency than emmer in Middle Neolithic and later deposits (Hansen 1991:83-84).

The plant impressions on Early Neolithic sherds from the Paralia can be securely associated with Franchthi Botanical Zone VI (IN) or a later EN phase through the sherds' placement within the Franchthi Cave Pottery (FCP) phasing developed by Vitelli (1993). In Vitelli's scheme, Interzone 0/1 (Int 0/1) corresponds to the IN, and is characterized by a paucity of sherds. According to Vitelli, all of the sherds associated with Int $0 / 1$ "are body sherds typical of FCP1 [Franchthi Ceramic Phase 1] varieties" (Vitelli 1993:38), corresponding to EN, while FCP Interphase 1/2 corresponds to the EN to MN transition (Vitelli 1993). Four of the Franchthi sherds with impressions are associated with FCP1, and one with FCP Interphase 1/2 (Vitelli 1993). Because the plant impressions were formed at the time when the clay was still soft, and they date to EN, the plants that created the impressions also date to EN. As such, this re-discovery of latex impressions of seeds that Hansen produced from Early Neolithic sherds recovered from the Paralia is significant for two reasons. First, it provides the only botanical evidence available for the area outside the cave, where Hansen (1991) posited that most plant processing was likely to have taken place. Second, the identification of two impressions of einkorn wheat grains on these sherds pushes back its appearance at Franchthi by several centuries, from $\mathrm{MN}$ to $\mathrm{EN}$.

With only two impressions of einkorn grain, it is not possible to determine whether or not it was grown as a crop in its own right. Similarly, the quantity of seeds represented in the Franchthi Botanical Zone VI macrobotanical assemblage is also quite low, with just 38 whole items and 27 fragments (Hansen 1991:Appendix D). Together with lentil ( $\mathrm{n}=11$, whole, 1 fragment), emmer $(\mathrm{n}=9)$ is the only taxon that occurs regularly (Hansen 1991:139). Although this study has expanded the range of Early Neolithic cereal crops represented at Franchthi, the small assemblage of plant remains recovered from these deposits precludes determination of the role of any of these cereal types in the agricultural system or diet of the population at Franchthi during Early Neolithic. For Franchthi Botanical Zone VIIa (MN), in which einkorn seeds and chaff are first attested in the cave in the FAN sequence, the high ratio of emmer to einkorn seeds (6.41:1 for complete specimens and 2.4:1 for fragments) and chaff (1.6:1) points toward einkorn's status at Franchthi as a tolerated weed rather than a crop in its own right, like emmer.

On the basis of the regular occurrence of einkorn in Northern Greece, several scholars have posited a northern and southern divide in wheat types, with einkorn dominant in the north and emmer in the south (Marinova and Valamoti 2014; Valamoti and Kotsakis 2007). Although this pattern is intriguing and warrants further examination, given the presence of only two Early Neolithic assemblages from southern Greece, Franchthi Cave (Hansen 1991) on the mainland and Knossos on Crete (Sarpaki 2013), it is difficult at present to argue convincingly for any clear regional patterning. Instead, the recovery of a previously unreported taxon at Franchthi from a small quantity of impressions further highlights the problem of small Early Neolithic assemblages from Greece as a whole, such that even small datasets-including those from seed impressions-have a higher potential to change the narrative for the Early Neolithic than for better attested periods.

\section{Conclusions}

The identification of einkorn in impressions on ceramic sherds from the Franchthi Paralia pushes back the appearance of einkorn at Franchthi from the Middle Neolithic, as documented in plant macroremains from Franchthi Botanical Zone VII, to the Early Neolithic, known only from its earliest phase in Franchthi Botanical Zone VI. Many Early Neolithic sites in the Aegean have small botanical assemblages, even when intensive sampling and flotation with the use of small mesh sizes are applied. Careful examination of ceramic sherds to assess the presence of plant impressions can provide evidence that complements sparse macrobotanical assemblages. For site phases where plant remains are especially few, as is the case for the Franchthi Cave Early Neolithic assemblage, the potential for plant impressions to expand the range of taxa is higher than for site phases where plant remains are abundant. 


\section{Notes}

${ }^{1}$ Because the Early Neolithic deposits at Franchthi are poorly dated (Perlès 2001, Perlès et al. 2013), it is not possible to provide a more precise length of time for the difference, but Perlès (personal communication) suggests that it is not more than a few centuries.

${ }^{2}$ According to Hansen (personal communication December, 2017), the grains depicted in her Figure 41 are einkorn, despite having been captioned as "Triticum turgidum ssp. diccoccum," an error that was not caught during the editing process.

\section{Acknowledgements}

I sincerely thank Karen D. Vitelli for permission to publish the Franchthi impressions and for her thoughtful comments on the text, and Catherine Perlès for feedback on an initial draft and insightful discussion of chronology, phasing, stratigraphy, and other issues. Julie Hansen provided both encouragement and essential clarification of her methodology. Chantel White, Mac Marston, and two anonymous reviewers also provided helpful feedback on earlier drafts of this article and suggestions for its improvement. I also thank Lora Arduser and Kathleen Forste for their moral support during research and writing.

\section{Declarations}

Permissions: Permission to study and publish these materials was granted by Dr. Karen D. Vitelli.

Sources of Funding: This research was facilitated by a University of Cincinnati Arts, Humanities, and Social Sciences Research Advisory Board Third Century Faculty Release Fellowship.

Conflicts of Interest: There are no conflicts of interest to declare.

\section{References Cited}

Hansen, J.M. 1991. The Palaeoethnobotany of Franchthi Cave. Excavations of Franchthi Cave, Fascicle 7. Indiana University Press, Bloomington, IN.

Hansen, J.M. and J.M. Renfrew 1978. PalaeolithicNeolithic Seed Remains at Franchthi Cave, Greece. Nature 271:349-352.

Helbaek, H. 1955. The Botany of the Vallhager Iron Age Field. In Vallhagar. A Migration Period Site on Gotland, Sweden, edited by M. Steinberger, pp. 653699. Munksgaard, Copenhagen.
Hubbard, R.L.N. 1992. Dichotomous Keys for the Identification of the Major Old World Crops. Review of Palaeobotany and Palynology 73:105-115.

Jacomet, S. 2006. Identification of Cereal Remains from Archaeological Sites. 2nd Edition. Archaeobotany Lab, IPAS, Basel University, Basel, Switzerland.

Kroll, H. 1992. Einkorn from Feuvdar, Vojvodina, II. What is the Difference between Emmer-Like TwoSeeded Einkorn and Emmer? Review of Palaeobotany and Palynology 73:181-185. DOI:10.1016/0034-6667 (92)90056-M.

Marinova, E. and S.-M. Valamoti 2014. Crop Diversity and Choice in Prehistoric Southeastern Europe: Cultural and Environmental Factors Shaping the Archaeobotanical Record of Northern Greece and Bulgaria. In Plants and People: Choices and Diversity through Time, edited by A. Chevalier, E. Marinova, and L. Peña-Chocarro, pp. 64-74. Oxbow, Oxford, UK.

Megaloudi, F. 2006. Plants and Diet in Greece from Neolithic to Classical Periods. The Archaeobotanical Remains. British Archaeological Reports, Oxford, UK.

Munro, N.D. and M.C. Stiner 2015. Zooarchaeological Evidence for Early Neolithic Colonization at Franchthi Cave (Peloponnese, Greece). Current Anthropology 56:596-603. DOI:10.1086/682326.

Perlès, C. 1987. Les Industries Lithiques Taillees de Franchthi, Vol. II. Excavations of Franchthi Cave, Fascicle 5. Indiana University Press, Bloomington, IN.

Perlès, C. 2001. The Early Neolithic in Greece. Cambridge University Press, Cambridge, UK.

Perlès, C., A. Quiles, and H. Valladas 2013. Early Seventh-Millennium AMS Dates from Domestic Seeds in the Initial Neolithic at Franchthi Cave (Argolid, Greece). Antiquity 87:1001-1015. DOI:10.1017/S0003598X00049826.

Renfrew, J.M. 1973. Palaeoethnobotany: The Prehistoric Food Plants of the Near East and Europe. Columbia University Press, New York, NY.

Sarpaki, A. 2013. The Economy of Neolithic Knossos: The Archaeobotanical Data. In The Neolithic Settlement of Knossos in Crete: New Evidence for the Early Occupation of Crete and the Aegean Islands, edited by Nikos Esfratiou, A. Karetsou, and M. Ntinou, pp. 63-94. Institute for Aegean Prehistory Press, Philadelphia, PA. 
Valamoti, S.M. 2004. Plants and People in Late Neolithic and Early Bronze Age Northern Greece: An Archaeobotanical Investigation. BAR International Series 1258. British Archaeological Reports, Oxford, UK.

Valamoti, S.M. and K. Kotsakis 2007. Transitions to Agriculture in the Aegean: The Archaeobotanical Evidence. In The Origins and Spread of Domestic Plants in Southwest Asia and Europe, edited by S. Colledge and J. Connolly, pp, 75-91. Left Coast Press, Walnut Creek, CA.

Vitelli, K.D. 1993. Franchthi Neolithic Pottery. Excavations at Franchthi Cave, Greece, Fascicle 8, Vol. 1. Indiana University Press, Bloomington, IN. 